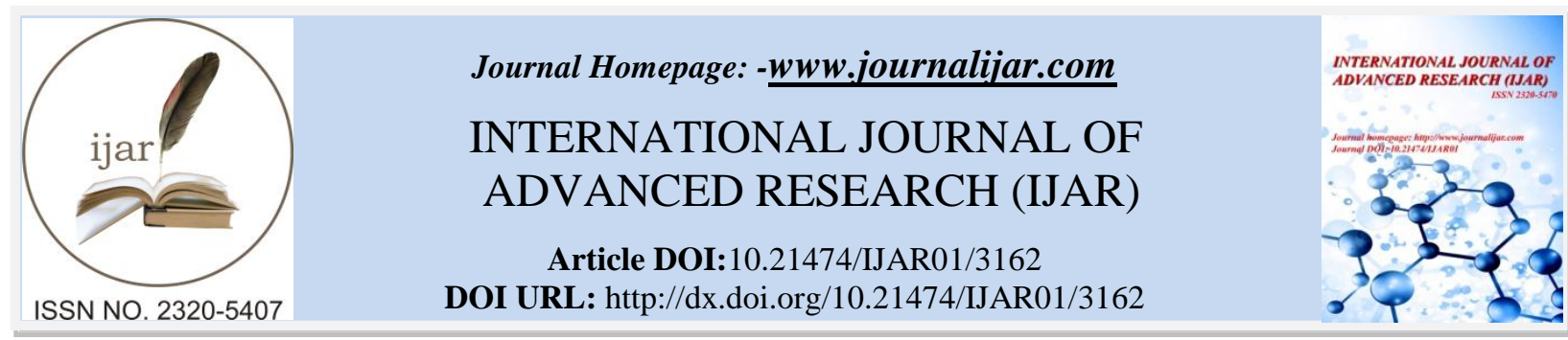

RESEARCH ARTICLE

\title{
DHAM (TRADITIONAL FEAST OF MANDI IN HIMACHAL PRADESH) A COMPLETE FOOD WITH AYURVEDA PERSPECTIVE.
}

\author{
Sumeet Goel ${ }^{1, *}$, Deepshika Arya ${ }^{1}$, Vineeta Negi ${ }^{1}$, Vikas Nariyal ${ }^{1}$, Prashant Shinde ${ }^{1}$ and \\ Om Raj Sharma ${ }^{2}$. \\ 1. Research Officer Regional Ayurveda Research Institute for Nutritional Disorders, Mandi, H.P. \\ 2. Assistant Director and Research Officer Regional Ayurveda Research Institute for Nutritional Disorders,
} Mandi, H.P.

\section{Manuscript Info}

n.......................

Manuscript History

Received: 18 December 2016

Final Accepted: 20 January 2017

Published: February 2017

Key words:-

Ahara, Ayurveda, Dham, Himachal

Pradesh, Mandi, Proper Diet

\section{Abstract}

In Ayurveda,Ahar(food) is considered as one of a major tripod of life. As per Ayurveda a good diet consist of all six rasa and are taken in proper sequence of Madhurafollowed by Amla, Lavana, Katu, Tiktaand Kashaya. Dhamis a popular traditional feast of Himachal Prasdesh (H.P.), which is a good example of complete food as per Ayurveda having all six rasa and is served in proper sequence. The dish composed of a sweet (boondikameetha) followed by SepuBadi, kaddukakhatta, kolkakhatta, mahkidaaland in the end of diet jhol. Served in pattal(plates made of leaves ofTaur -bauhinia vahli) which have good antioxidant properties. The preservation method used in the region of ingredients of dham is also traditional as no chemical is used. All these make up dhama complete diet in terms of Ayurveda and also in terms of nutrition. Present study deals with various Ayurveda and scientific aspects of dhamand its importance.

Copy Right, IJAR, 2017,. All rights reserved.

\section{Introduction:-}

Food (Ahara) is one of the tripods of life as per Ayurvedic classics ${ }^{\mathrm{i}}$. Among the three Upasthambha, Ahara is considered as the best sustainer of life (VrittikaranamSreshtam) ${ }^{\mathrm{ii}}$. Region wise food habits changes, which is important as per the climate and conditions prevailing in the region. But in present era with fast changing food habits and more and more use of canned food, chemical preservatives and junk foods, health is getting compromised. In order to preserve the health, food serves an important factor which must be given due importance. Ayurveda has incorporated various explanations regarding this vital pillar of life. This includes the classification of foods according to the geographical area and also with respect to the bodily Tri-Dosha andSatvikadiguna, different processing methods of food, importance and role of food on the body and mind, wholesome and unwholesome diets and the pattern of metabolism.

Himachal is a culture in terms of various nutritious traditional food, playing a role in everyday life as well as in festivals. In many families, everyday meals are sit-down affairs consisting of two to three main course dishes, carbohydrate staples such as Rice, varied protein and micronutrient rich accompaniments such as pulses and vegetables, as well as sweets. The people of H.P. have developed traditional food processing technologies for preparing the foods from locally available substrates largely governed by the ethnic preference, agro climatic 
conditions, sociocultural ethos and religion. However, there may be local variation from region to region. A number of traditional foods are prepared and consumed by people in Himachal Pradesh for centuries, and these form a part of sociocultural life of the hill people $\mathrm{i}^{\mathrm{iii}-\mathrm{iv}}$.

\section{Aim of study:-}

This review aims at scanning the scattered literature on proper diet in accordance with Ayurveda with special reference to a traditional food called as Dhamof Mandi, H.P.

\section{Method:-}

Classical texts of Ayurveda as well as PUBMED, MEDLINE database and relevant journals were used for the search of relevant literature and research papers. Papers published between Jan 1960 to Jan 2017 were only considered. The key words used for the search was 'Ayurveda', 'Shad Rasa' 'Ahara' 'Traditional food' and 'Dham' etc. information from conversation from local inhabitant of Mandiwere also included in the review to search out and understand proper tradition of preparing, preserving and serving of Dham. Only research articles published in English language were considered.

\section{Dham (Traditional feast of H.P.):-}

In H. P. during functions and marriages, traditional community meal is prepared which is called Dham. Dham is a traditional festive meal, cooked only by botis (a particular caste of Brahmins who are hereditary chefs). Preparations for this elaborate mid-day meal begin a night before. Food is cooked in big brass utensils or mud pots and everyone sits on the ground in rows to have food ${ }^{\mathrm{v}}$. In the present study Dham specifically of Mandi is being discussed.

As Sushrut explain the proper sequence of having meals and have mention that a proper diet should include all six rasa. In the beginning of foodSweet -Madhuradominant food should be taken then in the middleSour AmlaandSalty-Lavandominant food and toward the end of foodPungent -Katu,Bitter -Tikta, and Astringent Kashaya rasa dominant diet should be taken ${ }^{\text {vi }}$.

Dhamprepared in the traditional way is an example of shadrasaahara(food with all six rasa) which is considered as a complete food as per Ayurveda and also served in the proper sequence of rasa.

The starters begins with madhur rasa (sweet dish),BoondikaMeetha(prepared from chickpea floor) dipped in sweet syrup along with dry fruits).

The next item comes SepuBadi, It is prepared from fresh spinach leaves and badi. Badi constitute of Masha (black lentil) and Chana (Bengal gram) deeply fried with the gravy of coriander and spinach leaves giving it aMadhuraAmla rasa (Sweet- Sour).

Then comes Amla- lavana Rasa (Sour- Salty)Kadukakhata Prepared from pumpkins and giving the dish a blend of sweet and sour taste.

Then comes kolkakhata (makushtabheda -Vignaaconitifolia). Prepared from the pulse commonly known askol. It is sour and brings a grimace on face. Added with Rai powderit is Katurasa (pungent taste) dominant.

Then comes Mahkidaalthat is masha (black lentils) thepulse is prepared with Fennel seeds, two three bay leaves, Green Cardamoms, Black Cardamoms, small stick of Cinnamon, Cloves, Coriander seeds, Bay leaves, Curd, Spinach, pinch of Asafetida, red chili powder, coriander powder and turmeric powder making it a tiktapradran (Bitter dominant) dish.

At last Jholwhich iskashay rasa (Astringent) dominant is regular prepared item in house of every Mandyali (native people of Mandi), prepared from curd and water in mud pot. In the local terms it is said "the food wouldn't digest until a glass of Jhol is not drunk" goes in accordance with Ayurveda. Itsrukhsaguna which may help in cleansing of esophagus and gut from Ghrita rich food. Moreover as it is made up takra(butter milk) as its main ingredient hence it serves as a great Pachana (Digestive) ${ }^{\text {vii }}$ especially of ghee $\&$ oil $^{\text {viii }}$. 


\section{Eating and Serving Styles:-}

Eating with your hands is considered important in Indian etiquette because a person eating with his hands knows the exact temperature of food before the morsel hits his mouth thus preventing blisters in mouth due to consumption of hot food ${ }^{\mathrm{ix}}$. In H.P. specifically in Mandi region, a cleaned Taur-bauhinia vahlileaves are most commonly used ${ }^{\mathrm{x}}$ as a hygienic and visually interesting alternative to plates. The leaves have health benefits too in terms of antimicrobial effect and antioxidant properties ${ }^{\mathrm{xi}}$. In addition the plant leaves are completely biodegradable. It also provide job and income to less privileged rural people thus forming one of the importantpart of rural economy in H.P. ${ }^{\text {xii }}$

\section{Nutritional and medicinal value:-}

Black gram (Masha - Vigna mungo) content of sepubadiandmahki dal is Snigdha (unctuous), Balya (increases strength), increases Kapha and Pitta, Malakara (increases bulk of faeces), Sara (laxative), Guru (not easily digestible), Ushna (hot in potency), Vatahara (mitigate Vata), Madhura (sweet in taste), and ShukraVriddhikara (aphrodisiac properties) $^{\text {xiii }}$. Black gram is very nutritious as it contains high levels of protein $(25 \mathrm{~g} / 100 \mathrm{~g})$, potassium $(983 \mathrm{mg} / 100 \mathrm{~g})$, calcium $(138 \mathrm{mg} / 100 \mathrm{~g})$, iron $(7.57 \mathrm{mg} / 100 \mathrm{~g})$, niacin $(1.447 \mathrm{mg} / 100 \mathrm{~g})$, Thiamine $(0.273 \mathrm{mg} / 100 \mathrm{~g})$, and riboflavin $(0.254 \mathrm{mg} / 100 \mathrm{~g}){ }^{\text {xiv }}$ Black gram complements the essential amino acids provided in most cereals and plays an important role in the diets of the people of Nepal and north India. ${ }^{\mathrm{xv}}$ Black gram has been shown to be useful in mitigating elevated cholesterol levels ${ }^{\text {xvi-xvii }}$.

Bengal gram also called as chickpea (chana dal-Cicer arietinum) content of sweet and sepubadiis useful in throat problems, blood disorders, bronchitis, skin diseases and liver or gall bladder related problems [biliousness] ${ }^{\text {xiii }}$. In addition to these applications, the chickpea seeds are also used for blood enrichment, treating skin ailments, ear infections, and liver and spleen disorders ${ }^{\text {xix }}$. It is rich in nutritionally important unsaturated fatty acids like linoleic and oleic acid. $\beta$-sitosterol, campesterol and stigmasterol are important sterols present in chickpea oil. Calcium, magnesium, phosphorus and especially potassium are also present in chickpea seeds. It is a good source of important vitamins such as riboflavin, niacin, thiamine, folate and the vitamin A precursor, $\beta$-carotene ${ }^{\mathrm{xx}}$.

Kolki dal (Vignaaconitifolia): It is quite different from Mothki dal described in Ayurved as it is bigger than original moth, and both are available in this region though as per botanical classification the latin name of both these pulses are same but as per locals both type of pulses are available in Mandi region the one commonly known as moth dal and the other which is used in Dhamcalled as kolki dal. Vignaaconitifoliais rich in (values per 100 gm) calcium 150mg, iron $10.8 \mathrm{mg}$, magnesium $381 \mathrm{mg}$, manganese $1.8 \mathrm{mg}$, phosphorus $489 \mathrm{mg}$, potassium $1191 \mathrm{mg}$, sodium 30 $\mathrm{mg}$ and zinc $1.9 \mathrm{mg}$ along with thiamine, riboflavin, niacin, panthothenic acid, folate and Vitamin C. Among macronutrients it contains 343 calories, $23 \mathrm{~g}$ of protein, $62 \mathrm{~g}$ of carbohydrate and $1.6 \mathrm{~g}$ of fat ${ }^{\mathrm{xxi}}$.

Jhol(spiced butter milk): buttermilk is a rich source of Vitamin B12, calcium, Riboflavin and probiotics which help strengthen the digestive system and the immunity of the body. Takra (Buttermilk) is very useful in the diseases associated with the Agni Vikriti. By means of its Properties it acts as Tridoshaghana(Vitiate all three doshaof body) $)^{x x i i}$.

The utensils used for cooking sweet is iron vessels which gives extra benefit of iron, moreover loss of nutrients in iron vessels, brass vessels and mud pot cooking (used for making other dishes of dhamother than the sweet) are also very less as compared to aluminum and cooker cooking of food.

\section{Seasonalconsideration:-}

During winter season due to the contact with cold wind, the digestive power of healthy people get increased and

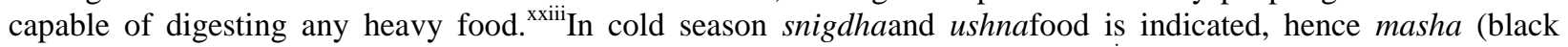
gram) and Ghrita dominant diet is a good and nutritious food in this region ${ }^{\text {xxiv }}$. Hence Dhamis a good food especially for cold hill region of Himachal. Moreover cooking it with plenty of spices and use of jholat the end of food also helps in proper digestion of the dish.

\section{Influence of Mana (Mental Factors) on Digestion:-}

Acharya Charaka mentioned the influence of negative emotions on the digestion of food ${ }^{\mathrm{xxv}}$. Healthy and wholesome food if taken even in proper quantity do not get properly digested when the individual is afflicted with grief, fear, anger, sorrow, excessive sleep and excessive vigil. This is also considered in having Dhamas it is served in festive mood, where all people gather and have this dish together sitting on ground with the feeling of equality and happiness. 


\section{Natural Preservation:-}

Rice being the main food is generally preserved by drying in $\operatorname{sun}^{\mathrm{xxvi}}$ and instead of using sodium benzoate (preservative), they use more rai which acts as a natural preservative owing to its good antimicrobial activity ${ }^{\text {xxvii }}$. And they also have unique way for preserving raw pulses for longer periods, in which they rub the pulses with mustard oil which protects it from pests and fungus. And they also treat the utensils in which these are kept, with smoke of red 'mirchi' (chili). It helps in longer preservation ${ }^{\mathrm{xxviii}}$.

\section{Conclusion:-}

India is a rich culture. Many of the Traditional practices, food habits have a scientific basis, though with course of time many wrong practice may have prevailed, but some practices like the food habits of different region have been studies from time to time and have been found to have better nutritional value and found in accordance with Ayurveda. One such dish popular in Mandi H.P. known as dhamhave been reviewed and found to follow the definition of proper diet as described in Ayurveda. Hence it can be concluded from the present study that such traditional food should be conserved and be made popular so the people may understand the importance of traditional food, and the method of traditional preservation and sequence of serving should be conserved which is getting changed with time as it may prove detrimental to the benefits which traditionally made and served dhammay provide. As popularly said in Ayurveda: If one eats pathya (Proper food) then there is no need of medicine and if one don't eat pathya(takes improper diet) still there will be no need of medicine ${ }^{\text {xix }}$.

\section{Acknowledgement:-}

The author expresses sincere thanks to the Director General, CCRAS, New Delhi for theirguidance and help.

\section{References:-}

${ }^{\mathrm{i} A g n i v e s h a: ~ C a r a k a ~ s a m h i t a, ~ V o l u m e ~ I I ~ w i t h ~ C a r a k a ~ C h a n d r i k a, ~ H i n d i ~ c o m m e n t a r y ~ E d i . ~ b y ~ B r a h m a n a n d ~ T r i p a t h i, ~}$ Published by Chaukhambha Sanskrit Prakashan, Varanasi, reprint 2004, Sutra sthana:11/16

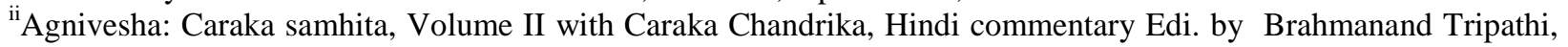
Published by Chaukhambha Sanskrit Prakashan, Varanasi, reprint 2004, Sutra sthana: 25/40

iii Thakur N, Kumar D, Savitri\&Bhalla TC, Traditional fermented foods and beverages of Himachal Pradesh,Invention Intelligence; 2003;173-178.

iv Thakur N, Savitri\&Bhalla TC, Characterization of some traditional fermented foods and beverages ofHimachal Pradesh, Indian J Traditional Knowledge, 3; 200; 325-335.

${ }^{v}$ Savitri, Tek Chand Bhalla; Traditional foods and beverages of Himachal Pradesh; Indian Journal of Traditional Knowledge, Vol. 6(1), January 2007, pp. 17-24

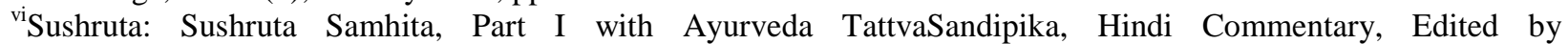
KavirajaAmbikadattaShastri, Published by Chaukhambha Sanskrit Sansthan, Varanasi, 14th edition, 2003. Sutrasthana 46/466

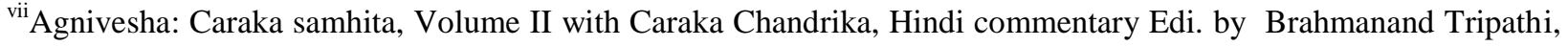
Published by Chaukhambha Sanskrit Prakashan, Varanasi, reprint 2004, Sutra sthana: 2/19

viii Agnivesha: Caraka samhita, Volume II with Caraka Chandrika, Hindi commentary Edi. by Brahmanand Tripathi, Published by Chaukhambha Sanskrit Prakashan, Varanasi, reprint 2004, Sutra sthana.2/30

${ }^{\text {ix }}$ Sankpal, N. V., Joshi, A. P., Kulkarni, B. D. Journal of Microbiology and Biotechnology, 2002;10(3), 51-55.

${ }^{x}$ Socio-Economic Status Of Families Engaged In Pattal (Leaf Plates) Making In Himachal Pradesh And Jammu \& Kashmir; National Afforestation and Ecodevelopment Board (Ministry of Environment and Forests, GoI) Dr YS Parmar University of Horticulture and Forestry Nauni, Solan (HP) Retrieved on 27/Jan/2017 from: http://www.yspuniversity.ac.in/rc/reports/Pattal-StudyFinal.docx

${ }^{x i}$ Rajani Chauhan, Sonia Saklani; Bauhinia vahlii: plant to be explored; Int. Res. J. Pharm.4 (8); 2013

${ }^{x i i}$ Macqueen, D.J.; The role of small and medium forest enterprise association in reducing poverty. International Institute for Environment and Development (IIED), Natural Resources Group, Scotland. 2009. Retrieved on 27/Jan/2017 from: http://www.fao.org/docrep/010/ag131e/ag131e23.htm

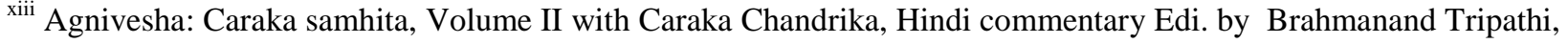
Published by Chaukhambha Sanskrit Prakashan, Varanasi, reprint 2004, Sutra sthana: 27/24

xiv "Mungo beans, mature seeds, raw". USDA National Nutrient Database for Standard Reference. US Department of Agriculture. Retrieved on 27/ January/2017 from: http://ndb.nal.usda.gov/ndb/foods/show/4796 
xv "Post-Harvest Profile of Black Gram". Government of India, Ministry of Agriculture. 2006. Retrieved on 27/ January/2017 from: http://agmarknet.nic.in/BlackGram1.pdf

xvi Menon, P. V.; Kurup, P. A.;"Dietary fibre and cholesterol metabolism: Effect of fibre rich polysaccharide from blackgram (Phaseolus mungo) on cholesterol metabolism in rats fed normal and atherogenic diet". Biomedicine/24 (4): 248-53; 1976 PMID 990375

xvii Indira, M.; Kurup, P.A.; "Black Gram: A Hypolipidemic Pulse". Natural Product Radiance 2 (5): 2013

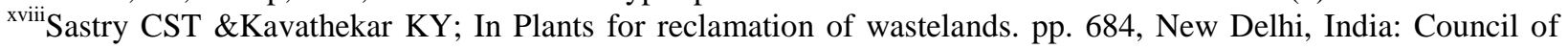
Scientific and Industrial Research; 1990

${ }^{\text {xix }}$ Warner PKW, Nambiar VPK \&Remankutty C; In Indian medicinal plants, pp. 773-774. Chennai, India: Orient Longman.1995

${ }^{x x}$. K. Jukanti, P. M. Gaur, C. L. L. Gowda and R. N. Chibbar; Nutritional quality and health benefits of chickpea (Cicer arietinum L.): a review; British Journal of Nutrition; Vol.:108(1); S11-S26, August 2012

${ }^{x x i}$ U.S. Department of Agriculture, Agricultural Research Service. USDA National Nutrient Database for Standard Reference, Release 26. Nutrient Data Laboratory Home Page, Retrieved on 27/Jan/2017 from https://www.ars. usda .gov/northeast-area/beltsville-md/beltsville-human-nutrition-research-center/nutrient-data-laboratory

${ }^{x x i i}$ RajendraNirgude, Sandeep V. Binorkar, Gajanan R. Parlikar, Milind C. Kirte. Therapeutic and nutritional values of takra (buttermilk); International Research Journal Of Pharmacy; 4 (2): 2013

xxiii Agnivesha: Caraka samhita, Volume II with Caraka Chandrika, Hindi commentary Edi. by Brahmanand Tripathi, Published by Chaukhambha Sanskrit Prakashan, Varanasi, reprint 2004, Sutra sthana: 6

${ }^{\text {xxiv }}$ Sushruta: Sushruta Samhita, Part I with Ayurveda TattvaSandipika, Hindi Commentary, Edited by KavirajaAmbikadattaShastri, Published by Chaukhambha Sanskrit Sansthan, Varanasi, 14th edition, 2003. Sutra sthan $46 / 474$

${ }^{x x v}$ Agnivesha: Caraka samhita, Volume II with Caraka Chandrika, Hindi commentary Edi. by Brahmanand Tripathi, Published by Chaukhambha Sanskrit Prakashan, Varanasi, reprint 2004, Vimana Sthana 2/9

${ }^{x x v i}$ What is the importance of food preservation, Retrieved 26 January, 2017 from http://www.preservearticles.com /201105176772/what-is-the-importance-of-food preservation.html

xxvii KarwanSedeeq Mohammed; antimicrobial activity of pepper, black seed, mustard and olive against five pathogenic microorganisms. International Journal of Biological \& Pharmaceutical Research. 2013; 4(9): 651-654

xxviii Dr. Venkata Krishnan; Study of traditional methods of food preservation, its scientific understanding and technological intervention; ISTP (Group-7) FINAL REPORT; 2014, Retrieved 26 January, 2017 from http://www. iitmandi.ac.in/ istp/projects/2014/projsect7.html

${ }^{x x i x}$ Lolimbraj, Vaidyajivan with Hindi commentary "Vidyotani”" by Dr.Indradev Tripathi, Chaukhambha oriantilia, Varanasi, reprint, 2007 